\title{
Studi Kinetik Proses Koagulasi dengan Koagulan Poly Aluminium Chloride dan Tawas dalam Pengolahan Limbah Cair Industri Tempe
}

\section{Kinetic Study on Coagulation Process with Poly Aluminium Chloride and Alum Coagulants in Treating The Liquid Waste of Tempeh Industry}

\author{
Iqbal Syaichurrozi ${ }^{\mathrm{a} *}$ \\ ${ }^{a}$ Jurusan Teknik Kimia, Fakultas Teknik, Universitas Sultan Ageng Tirtayasa, Jl. Jendral Soedirman Km 3, Cilegon 42435, \\ Provinsi Banten, Indonesia
}

\section{Artikel histori : \\ Diterima 15 Agustus 2021 \\ Diterima dalam revisi 27 Agustus 202 Diterima 03 September 2021 Online 1 November 2021}

\begin{abstract}
ABSTRAK: Beberapa faktor yang mempengaruhi proses koagulasi dalam pengurangan chemical oxygen demand (COD) pada limbah cair adalah waktu proses, dosis koagulan dan jenis koagulan. Penelitian pengaruh ketiga faktor tersebut terhadap pengurangan COD pada limbah cair industri tempe selama proses koagulasi telah dilakukan oleh Hidayah (2018). Akan tetapi, studi kinetik secara mendalam belum dilakukan oleh Hidayah (2018). Oleh karena itu, tujuan studi ini adalah untuk menyusun model kinetik baru yang dapat memprediksi unjuk kerja proses koagulasi. Diharapkan model kinetik tersebut dapat digunakan pada kondisi operasi yang lebih luas. Pada studi ini, model kinetik pseudo first order dan pseudo second order dibandingkan untuk mendapatkan model yang paling baik. Berdasarkan hasil simulasi, kedua model tersebut menghasilkan akurasi yang hampir sama. Dengan alasan simplifikasi, model pseudo first order dipilih sebagai model dasar pada studi ini. Selanjutnya dilakukan modifikasi pada model pseudo first order tersebut agar pengaruh waktu elektrolisis, dosis koagulan dan jenis koagulan muncul pada model tersebut. Model kinetik ini berhasil diuji untuk memprediksi unjuk kerja koagulasi hasil penelitian Hidayah (2018) dengan nilai ratarata Mean Absolute Percentage Error (MAPE) sebesar 10,8\%.
\end{abstract}

Kata Kunci: COD; Koagulasi; Model Kinetik; Poly Aluminium Chloride; Tawas

ABSTRACT: Several factors that influence the coagulation process in reducing chemical oxygen demand (COD) in wastewater are processing time, coagulant dose and type of coagulant. The effect of these three factors on the reduction of COD in tempeh industrial wastewater during the coagulation process has been investigated by Hidayah (2018). However, kinetic studies in depth have not been done by Hidayah (2018). Therefore, the aim of this study was to develop a new kinetic model that can predict the performance of the coagulation process. It is hoped that the kinetic model can be used in a wider range of operating conditions. In this study, the pseudo first order and pseudo second order kinetic models were tested to get the best model. Based on simulation results, both models produced almost the same accuracy. For reason of simplification, the pseudo first order model was chosen as the basic model in this study. Furthermore, modifications were made to the pseudo first order model so that the effect of processing time, coagulant dose and type of coagulant appeared in the model. This kinetic model was successfully tested to predict the coagulation performance of study of Hidayah (2018) with an average Mean Absolute Percentage Error (MAPE) of $10.8 \%$.

Keywords: COD; Coagulant; Kinetic Model; Poly Aluminium Chloride; Alum

\begin{abstract}
1. Pendahuluan
Koagulasi merupakan salah satu metode pengolahan limbah yang telah banyak diaplikasikan dalam pengolahan berbagai limbah industri seperti industri tekstil (Ayni dan Ningsih, 2021), industri penyamakan kulit (Moelyo, 2012), industri kertas (Sutiyono, 2006) dan industri tempe (Hidayah, 2018). Metode koagulasi memanfaatkan koagulan untuk mengikat polutan menjadi flok. Selanjutnya, flok-flok kecil saling berikatan membentuk flok yang besar yang kemudian mengendap sebagai endapan (Ayni dan Ningsih, 2021). Jenis koagulan yang dapat digunakan adalah poly aluminium
\end{abstract}

chloride (PAC) dan tawas (Hidayah, 2018). Reaksi kimia yang mungkin terjadi selama proses koagulasi disajikan pada persamaan (1-2).

Koagulan + polutan $\rightarrow$ Flok kecil

Flok kecil + Flok kecil $\rightarrow$ Endapan

Hidayah (2018) telah menguji proses koagulasi untuk mengurangi konsentrasi chemical oxygen demand (COD) pada limbah cair industri tempe. Hasil penelitian yang telah dilakukan Hidayah (2018) di tampilkan pada Tabel 1 dan 2. Pada Run 1-4 (Tabel 1), terlihat bahwa pengurangan

*Corresponding Author:

Email: iqbal_syaichurrozi@untirta.ac.id; iqbalsyaichurrozi@gmail.com 
konsentrasi COD pada limbah melalui proses koagulasi dipengaruhi oleh lama waktu proses dan dosis PAC. Semakin lama waktu proses, semakin besar pengurangan konsentrasi COD dan semakin besar dosis PAC, semakin besar pengurangan konsentrasi COD. Selanjutnya pada run 5-8 (Tabel 2), semakin lama waktu proses dan semakin besar dosis koagulan campuran (campuran PAC dan tawas) juga meningkatkan pengurangan konsentrasi COD pada limbah. Jika digabung Run 1-8, dapat disimpulkan bahwa proses koagulasi dipengaruhi oleh tiga faktor yaitu lama waktu proses, dosis koagulan dan jenis koagulan.

Pada laporan Hidayah (2018), konsentrasi massa PAC dan tawas dalam massa total koagulan campuran yang digunakan pada pada Run 5-8 belum dilaporkan secara spesifik. Oleh karena itu, pada studi ini penulis mengasumsikan bahwa perbandingan massa PAC dan massa tawas pada Run 5-8 adalah 50\%:50\%.

Tabel 1. Hasil proses koagulasi dalam pengolahan limbah cair industri tempe dengan koagulan PAC (Hidayah, 2018)

\begin{tabular}{lllllll}
\hline Run & Volume & Massa & \multicolumn{4}{l}{ Konsentrasi COD $(\mathrm{mg} / \mathrm{L})$ setelah waktu proses koagulasi } \\
\cline { 5 - 7 } & limbah $(\mathrm{L})$ & koagulan $(\mathrm{g})$ & 0 menit & 30 menit & 60 menit & 90 menit \\
\hline 1 & 0,05 & 10 & $62.056,7$ & $53.309,7$ & $51.300,2$ & $45.271,8$ \\
2 & 0,05 & 2,5 & $51.418,4$ & t.d. & t.d. & $42.671,3$ \\
3 & 0,05 & 5 & $51.418,4$ & t.d. & t.d. & $41.371,1$ \\
4 & 0,05 & 10 & $51.418,4$ & t.d. & t.d. & $36.997,6$ \\
\hline
\end{tabular}

Keterangan: t.d., tidak dianalisa

Tabel 2. Hasil proses koagulasi dalam pengolahan limbah cair industri tempe dengan koagulan campuran PAC dan tawas

\begin{tabular}{|c|c|c|c|c|c|c|}
\hline \multirow[t]{2}{*}{ Run } & \multirow{2}{*}{$\begin{array}{l}\text { Volume } \\
\text { limbah (L) }\end{array}$} & \multirow{2}{*}{$\begin{array}{l}\text { Massa } \\
\text { koagulan (g) }\end{array}$} & \multicolumn{4}{|c|}{ Konsentrasi COD (mg/L) setelah waktu proses koagulasi } \\
\hline & & & 0 menit & 30 menit & 60 menit & 90 menit \\
\hline 5 & 0,05 & 10 & $63.829,7$ & $53.782,5$ & $50.709,2$ & $48.463,3$ \\
\hline 6 & 0,05 & 2,5 & $59.219,8$ & t.d. & t.d. & $44.799,0$ \\
\hline 7 & 0,05 & 5 & $59.219,8$ & t.d. & t.d. & $37.825,0$ \\
\hline 8 & 0,05 & 10 & $59.219,8$ & t.d. & t.d. & $29.432,6$ \\
\hline
\end{tabular}

Keterangan: t.d., tidak dianalisa

Hidayah (2018) belum melakukan studi kinetik terhadap hasil penelitiannya. Oleh karena itu, pada studi ini, penulis melakukan studi kinetik untuk (1) menentukan model kinetik yang sesuai (dari dua model yang diujikan yaitu pseudo first order dan pseudo second order) pada kasus proses koagulasi dalam mengolah limbah cair industri tempe dan (2) menyusun model kinetik baru yang dapat digunakan untuk memprediksi unjuk kerja proses koagulasi pada berbagai waktu proses, dosis koagulan dan jenis koagulan.

\section{Data eksperimen dan model kinetik}

Studi ini fokus pada analisa kinetik. Data eksperimen diperoleh dari hasil penelitian yang telah dilaporkan oleh Hidayah (2018) yang telah disajikan pada Tabel 1 dan 2. Proses pengikatan COD oleh koagulan diasumsikan terjadi karena reaksi adsorpsi.

\subsection{Pseudo second order}

Proses penyerapan adsorbat oleh adsorben dapat dituliskan melalui persamaan (3). Diasumsikan bahwa setiap adsorbat (A) dapat diikat oleh dua sisi kosong adsorben (S) dan reaksinya irreversible (Xiao et al., 2018).

$\mathrm{A}+2 \mathrm{~S} \stackrel{k_{2}}{\rightarrow} \mathrm{AS}_{2}$

Dari persamaan (3), dapat disusun persamaan matematis yang ditunjukkan oleh persamaan (4) (Xiao et al., 2018).

$\frac{d C_{A S_{2}}}{d t}=k_{2} C_{A} C_{S}^{2}$

Xiao et al. (2018) mengasumsikan bahwa konsentrasi adsorbat di dalam cairan adalah konstan $\left(C_{A} \approx\right.$ konstan $)$.
Asumsi ini diambil diduga karena konsentrasi $C_{A}$ dianggap berlebih dibandingkan konsentrasi $C_{S}$, sehingga perubahan $C_{A}$ diabaikan. Nilai $C_{A S_{2}}$ proporsional dengan $Q_{t}$ dan nilai $C_{s}$ proporsional dengan $\left(Q_{e}-Q_{t}\right)$ yang ditunjukkan oleh persamaan (5) dan (6) (Xiao et al., 2018).

$C_{A S_{2}} \propto Q_{t}$

$C_{s} \propto\left(Q_{e}-Q_{t}\right)$

Oleh karena itu, persamaan (4) dapat dituliskan menjadi persamaan (7) (Xiao et al., 2018).

$\frac{d Q_{t}}{d t}=k_{2}^{\prime}\left(Q_{e}-Q_{t}\right)^{2}$

Dimana $k_{2}^{\prime}=k_{2} C_{A}$

Dengan initial condition $\mathrm{Q}_{\mathrm{t}}=0$ pada $\mathrm{t}=0$, persamaan (7) diintegralkan dan diperoleh persamaan (8) (Xiao et al., 2018).

$Q_{t}=\frac{k_{2}^{\prime} Q_{e}^{2} t}{1+k_{2}^{\prime} Q_{e} t}$

\subsection{Pseudo first order}

Dengan metode yang sama seperti penyusunan model kinetik pseudo second order, model kinetik pseudo first order dapat disusun dengan langkah sebagai berikut:

Pada pseudo first order, diasumsikan bahwa setiap adsorbat (A) diikat oleh satu sisi kosong adsorben (S) dan reaksinya irreversible, persamaan (9).

$\mathrm{A}+\mathrm{S} \stackrel{k_{1}}{\rightarrow} \mathrm{AS}$

Selanjutnya, persamaan (10) disusun berdasarkan reaksi kimia yang ditunjukkan oleh persamaan (9).

$\frac{d C_{A S}}{d t}=k_{1} C_{A} C_{S}$ 
Dengan asumsi $C_{A}$ konstan selama proses, nilai $C_{A S}$ proporsional dengan $Q_{t}$ dan nilai $C_{s}$ proporsional dengan $\left(Q_{e}-Q_{t}\right)$, maka persamaan (10) dapat ditulis menjadi persamaan (11).

$\frac{d Q_{t}}{d t}=k_{1}^{\prime}\left(Q_{e}-Q_{t}\right)$
Dengan initial condition $\mathrm{Q}_{\mathrm{t}}=0$ pada $\mathrm{t}=0$, persamaan (11) diintegralkan dan diperoleh persamaan (12).

$Q_{t}=Q_{e}\left(1-\exp \left(-k_{1}^{\prime} t\right)\right)$

Secara ringkas, model kinetik pseudo first order dan pseudo second order ditunjukkan pada Tabel 3 (Adeogun dan Balakrishnan, 2017; Ohale et al., 2020; Ngteni et al., 2020).

Tabel 3. Model kinetik yang dapat dipakai pada reaksi adsorpsi

\begin{tabular}{lll}
\hline Model kinetik & Persamaan matematis & Konstanta kinetik yang dicari \\
\hline Pseudo first order kinetic & $Q_{t}=Q_{e}\left(1-\exp \left(-k_{1}^{\prime} t\right)\right)$ & $Q_{e}$ dan $k_{1}^{\prime}$ \\
Pseudo second order kinetic & $Q_{t}=\frac{k_{2}^{\prime} Q_{e}{ }^{2} t}{1+k_{2}^{\prime} Q_{e} t}$ & $Q_{e}$ dan $k_{2}^{\prime}$ \\
\end{tabular}

Dimana $Q_{t}$ dihitung dengan persamaan (13)

$Q_{t}=\frac{V\left(C_{0}-C_{t}\right)}{W}$

Keterangan:

$Q_{t} \quad=$ kapasitas adsorpsi pada waktu t menit $(\mathrm{mg} / \mathrm{g})$

$Q_{e} \quad=$ kapasitas adsorpsi kesetimbangan $(\mathrm{mg} / \mathrm{g})$

$k_{1}^{\prime} \quad=$ konstanta kecepatan laju reaksi adsorpsi pada pseudo first order (/menit)

$k_{2}^{\prime} \quad=$ konstanta kecepatan laju reaksi adsorpsi pada pseudo second order (g/(mg.menit))

$t \quad=$ waktu proses (menit)

$V \quad=$ volume limbah $(\mathrm{L})$
$W \quad=$ massa $($ dosis $)$ koagulan $(\mathrm{g})$

$C_{0} \quad=$ konsentrasi COD awal limbah $(\mathrm{mg} / \mathrm{L})$

$C_{t}=$ konsentrasi $\mathrm{COD}$ limbah setelah pengolahan selama $\mathrm{t}(\mathrm{mg} / \mathrm{L})$

Karena data penelitian yang tersedia pada Tabel 1 dan Tabel 2 adalah konsentrasi COD ( $\mathrm{mg} / \mathrm{L})$, maka model kinetik pada Tabel 3 dimodifikasi menjadi model kinetik yang disajikan pada Tabel 4.

Tabel 4. Model kinetik hasil modifikasi

\begin{tabular}{lll}
\hline Model kinetik & Persamaan matematis & Konstanta kinetik yang dicari \\
\hline Pseudo first order kinetic & $C_{t}=C_{0}-\frac{W}{V} Q_{e}\left(1-\exp \left(-k_{1}^{\prime} t\right)\right)$ & $Q_{e}$ dan $k_{1}^{\prime}$ \\
Pseudo second order kinetic & $C_{t}=C_{0}-\frac{W}{V} \frac{k_{2}^{\prime} Q_{e}{ }^{2} t}{1+k_{2}^{\prime} Q_{e} t}$ & $Q_{e}$ dan $k_{2}^{\prime}$ \\
\hline
\end{tabular}

\section{Penyelesaian model dengan Ms.Excel}

Algoritma penyelesaian model kinetik menggunakan Ms. Excel adalah sebagai berikut:

a) Menulis data eksperimen $C_{t}$ pada Ms.Excel

b) Melakukan tebakan nilai konstanta kinetik yang dicari

c) Menghitung nilai $C_{t}$ melalui model kinetik dengan nilai konstanta kinetik hasil tebakan pada poin $b$

d) Menghitung indeks kesalahan Mean Absolute Percentage Error (MAPE) (Khair et al., 2017)

$M A P E=\frac{1}{n} \sum_{i=1}^{n}\left|\frac{C_{t_{i}} \text { eksperimen }}{C_{t_{i}} \text { terhitung }}\right| \times 100 \%$

e) Klik Data $\rightarrow$ Solver $\rightarrow$ pada set objective, isi cell MAPE $\rightarrow$ pada By Changing Variable Cells, isi cell konstanta kinetik yang dicari $\rightarrow$ pada To, klik Min

f) Klik Solve

g) Catat nilai konstanta kinetik yang diperoleh

h) Bandingkan nilai MAPE dari model-model kinetik yang diujikan

i) Model dengan nilai MAPE tertinggi ditetapkan sebagai model terbaik
Nilai MAPE berkisar antara 0-100\%. Lewis (1982) membagi empat interpretasi berdasarkan nilai MAPE (Tabel $5)$.

Tabel 5. Interpretasi berdasarkan nilai MAPE MAPE Interpretasi

$<10 \quad$ Highly accurate forecasting

10-20 Good forecasting

20-50 Reasonable forecasting

$>50 \quad$ Inaccurate forecasting

4. Hasil simulasi

4.1. Perbandingan model pseudo first order dan pseudo second order

Untuk menentukan model mana yang lebih baik antara model pseudo first order dan model pseudo second order, data Run 1 dan 5 digunakan karena memiliki data eksperimen perubahan konsentrasi COD per real time. Hasil simulasi untuk Run 1 dan Run 5 disajikan pada Gambar 1(A dan B). Sementara itu, nilai konstanta kinetik yang dicari ditunjukkan pada Tabel 6 . 


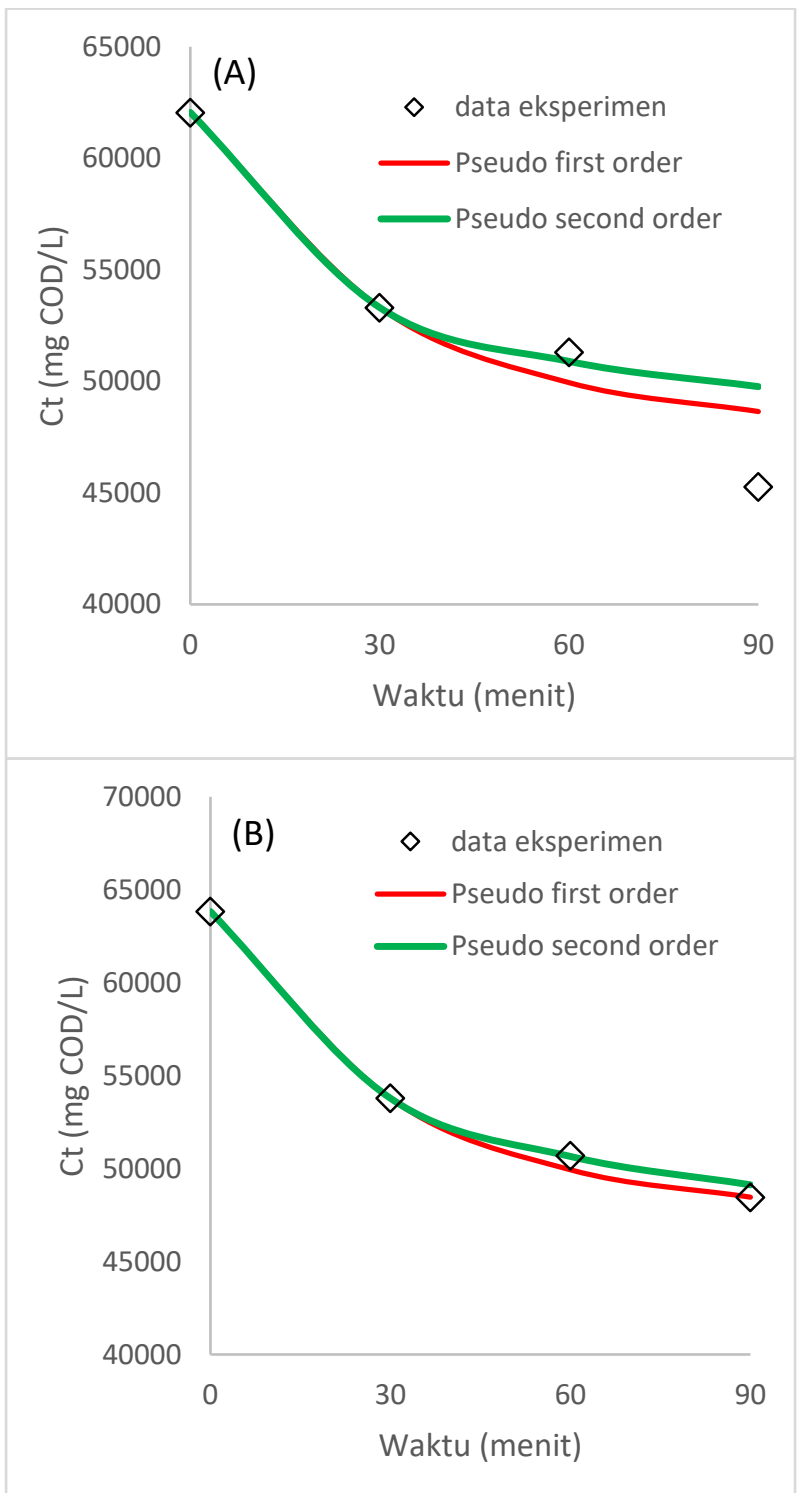

Gambar 1. Hasil simulasi pada (A) run 1 dan (B) run 5

Tabel 6. Nilai konstanta kinetik pada model pseudo first order dan pseudo second order untuk Run 1 dan Run 5

\begin{tabular}{ccc}
\hline Konstanta kinetik & Run 1 & $\begin{array}{c}\text { Run } 5 \\
\text { [PAC } 10 \mathrm{~g}]\end{array}$ \\
\hline [(PAC+tawas) $10 \mathrm{~g}]$ \\
\hline Pseudo first order & & \\
$Q_{e}(\mathrm{mg} / \mathrm{g})$ & 71,1 & 81,40 \\
$k_{1}^{\prime}(/ \mathrm{menit})$ & $3,2 \times 10^{-2}$ & $3,2 \times 10^{-2}$ \\
MAPE $(\%)$ & 10,1 & 1,5 \\
Pseudo second & & \\
order & & \\
$Q_{e}$ (mg/g) & 77,08 & 95,66 \\
$k_{2}^{\prime}$ g/(mg.menit) & $5,7 \times 10^{-4}$ & $3,9 \times 10^{-4}$ \\
MAPE $(\%)$ & 10,7 & 1,5 \\
\hline
\end{tabular}

Berdasarkan nilai MAPE, dua model yang diujikan memberikan hasil prediksi yang sama. Nilai MAPE yang diperoleh cenderung kecil dengan interpretasi highly accurate forecasting (Tabel 5). Karena pseudo first order memiliki persamaan matematis yang lebih sederhana, maka pseudo first order lebih dipilih dibandingkan model pseudo second order.

\subsection{Konstanta kinetik $\boldsymbol{k}_{1}^{\prime}$}

Berdasarkan Tabel 5, penggunaan koagulan PAC dengan koagulan campuran PAC dan tawas tidak berpengaruh terhadap nilai konstanta kinetik $k_{1}^{\prime}$. Oleh karena itu dapat diasumsikan bahwa nilai $k_{1}^{\prime}$ pada Run 2-4 serta Run 6-8 mempunyai nilai yang sama.

\subsection{Konstanta kinetik $Q_{e}$}

Berdasarkan Tabel 5, penggunaan koagulan PAC dengan koagulan campuran PAC dan tawas berpengaruh signifikan terhadap nilai konstanta kinetik $Q_{e}$. Hasil ini menunjukkan bahwa nilai $Q_{e}$ sensitif terhadap variabel jenis koagulan. Diasumsikan bahwa pada Run 5, persentase PAC dan tawas pada total massa koagulan campuran adalah $50 \%$ dan $50 \%$. Dengan kata lain, massa PAC dan tawas sebesar $5 \mathrm{~g}$ dan $5 \mathrm{~g}$ untuk menghasilkan $10 \mathrm{~g}$ massa total koagulan campuran. Begitu juga pada Run 6-8, diasumsikan bahwa persentase PAC dan tawas pada total massa koagulan campuran adalah $50 \%$ dan $50 \%$.

Selanjutnya, perlu dipastikan juga apakah jumlah koagulan mempengaruhi nilai $Q_{e}$ atau tidak. Nilai $Q_{e}$ pada Run 2-4 dan Run 6-8 dihitung dengan persamaan model pseudo first order dengan nilai $k_{1}^{\prime}$ diasumsikan sama yaitu $3,2 \times 10^{-2} /$ menit. Berdasarkan hasil perhitungan diperoleh data yang ditampilkan pada Tabel 7 .

Tabel 7. Pengaruh jenis dan jumlah koagulan terhadap nilai

\begin{tabular}{lllllll}
\hline Run & $\begin{array}{c}V \\
(\mathrm{~L})\end{array}$ & $\begin{array}{c}W \\
(\mathrm{~g})\end{array}$ & $\begin{array}{c}\text { Massa } \\
\text { PAC } \\
(\mathrm{g})\end{array}$ & $\begin{array}{c}\text { Massa } \\
\text { tawas } \\
(\mathrm{g})\end{array}$ & $\begin{array}{c}k_{1}^{\prime} \\
(/ \mathrm{menit})\end{array}$ & $\begin{array}{c}Q_{e} \\
(\mathrm{mg} / \mathrm{g})\end{array}$ \\
\hline 1 & 0,05 & 10 & 10 & 0 & $3,2 \times 10^{-2}$ & 71,1 \\
2 & 0,05 & 2,5 & 2,5 & 0 & $3,2 \times 10^{-2}$ & 185,5 \\
3 & 0,05 & 5 & 5 & 0 & $3,2 \times 10^{-2}$ & 106,5 \\
4 & 0,05 & 10 & 10 & 0 & $3,2 \times 10^{-2}$ & 76,5 \\
5 & 0,05 & 10 & 5 & 5 & $3,2 \times 10^{-2}$ & 81,4 \\
6 & 0,05 & 2,5 & 1,25 & 1,25 & $3,2 \times 10^{-2}$ & 305,6 \\
7 & 0,05 & 5 & 2,5 & 2,5 & $3,2 \times 10^{-2}$ & 226,7 \\
8 & 0,05 & 10 & 5 & 5 & $3,2 \times 10^{-2}$ & 157,8 \\
\hline
\end{tabular}

Tabel 7 menunjukkan bahwa nilai $Q_{e}$ dipengaruhi oleh jenis dan jumlah koagulan. Hubungan antara dua variabel bebas dengan variabel terikat dapat dituliskan melalui persamaan regresi linier berganda pada persamaan (15a) (Quirk, 2020) $a+b_{1} X_{1}+b_{2} X_{2}=Y$

Dimana $\mathrm{Y}=$ variabel terikat; $\mathrm{X}_{1}$ dan $\mathrm{X}_{2}=$ variabel bebas; $a$, $b_{1}, b_{2}=$ koefisien yang dicari.

Oleh karena itu, pada studi ini pengaruh jenis dan jumlah koagulan terhadap nilai $Q_{e}$ diasumsikan mengikuti persamaan regresi linier berganda tersebut. Persamaan (15a) disesuaikan dengan kasus stusi ini menjadi persamaan (15b). $\alpha+\beta m_{P A C}+\gamma m_{\text {Tawas }}=Q_{e}$ Dengan memanfaatkan aplikasi regresi pada Ms.Excel, diperoleh nilai koefisien $\alpha, \beta, \gamma$ sebagai berikut: 
$278,87-22,47 m_{P A C}-6,76 m_{\text {Tawas }}=Q_{e}$, dengan $\mathrm{R}^{2}=$ 0,85

\subsection{Penyusunan model kinetik baru}

Dari poin 4.1, model pseudo first order lebih dipilih dibandingkan pseudo second order karena alasan lebih sederhana. Berdasarkan Tabel 7, perbedaan jenis dan jumlah koagulan menyebabkan perbedaan nilai konstanta kinetik $Q_{e}$ dengan pendekatan nilai $k_{1}^{\prime}$ diasumsikan sama. Selanjutnya pada poin 4.3 , persamaan matematis yang menunjukkan pengaruh jenis dan jumlah koagulan terhadap nilai $Q_{e}$ berhasil disusun dan ditunjukkan pada persamaan (16). Pada poin ini akan dibuat model kinetik baru yang diharapkan dapat digunakan untuk memprediksi unjuk kerja proses koagulasi dalam pengolahan limbah cair industri tempe di berbagai kondisi proses yang meliputi waktu proses, jumlah koagulan dan jenis koagulan.

Persamaan (16) disubstitusikan ke persamaan kinetik pseudo first order dan nilai $k_{1}^{\prime}=3,2 \times 10^{-2} /$ menit sehingga diperoleh persamaan matematis yang ditunjukkan pada persamaan (17).

$C_{t}=C_{0}-\frac{W}{V}\left(278,87-22,47 m_{P A C}-6,76 m_{\text {Tawas }}\right)(1-$ $\left.\exp \left(-3,2 \times 10^{-2} t\right)\right)$

Validasi model (persamaan 17) dilakukan dengan menguji seluruh data yang ditampilkan pada Tabel 1 dan 2. Hasil prediksi pada semua run menggunakan model kinetik baru (persamaan (17)) ditampilkan pada Tabel 8 dan Gambar 2.

Tabel 8. Validasi model kinetik baru

\begin{tabular}{cccccccccc}
\hline Run & $\begin{array}{c}V \\
(\mathrm{~L})\end{array}$ & $\begin{array}{c}W \\
(\mathrm{~g})\end{array}$ & $\begin{array}{c}\text { Massa } \\
\text { PAC } \\
(\mathrm{g})\end{array}$ & $\begin{array}{c}\text { Massa } \\
\text { tawas }(\mathrm{g})\end{array}$ & $\begin{array}{c}C_{0} \\
(\mathrm{mg} / \mathrm{L})\end{array}$ & $\begin{array}{c}\text { Waktu } \\
\text { proses } \\
(\text { menit })\end{array}$ & $\begin{array}{c}C_{t} \\
\text { eksperimen } \\
(\mathrm{mg} / \mathrm{L})\end{array}$ & $\begin{array}{c}C_{t} \text { model } \\
(\mathrm{mg} / \mathrm{L})\end{array}$ & $\begin{array}{c}\text { MAPE } \\
(\%)\end{array}$ \\
\hline 1 & 0,05 & 10 & 10 & 0 & $62.056,7$ & 30 & $53.309,7$ & $55.371,0$ & 3,9 \\
& 0,05 & 10 & 10 & 0 & $62.056,7$ & 60 & $51.300,2$ & $52.868,7$ & 3,1 \\
& 0,05 & 10 & 10 & 0 & $62.056,7$ & 90 & $45.271,8$ & $51.919,6$ & 14,7 \\
2 & 0,05 & 2,5 & 2,5 & 0 & $51.418,4$ & 90 & $42.671,3$ & $40.899,4$ & 4,2 \\
3 & 0,05 & 5 & 5 & 0 & $51.418,4$ & 90 & $41.371,1$ & $35.703,6$ & 13,7 \\
4 & 0,05 & 10 & 10 & 0 & $51.418,4$ & 90 & $36.997,6$ & $41.281,3$ & 11,6 \\
5 & 0,05 & 10 & 5 & 5 & $63.829,7$ & 30 & $53.782,5$ & $47.286,7$ & 12,1 \\
& 0,05 & 10 & 5 & 5 & $63.829,7$ & 60 & $50.709,2$ & $41.046,8$ & 19,1 \\
& 0,05 & 10 & 5 & 5 & $63.829,7$ & 90 & $48.463,3$ & $38.693,1$ & 20,2 \\
6 & 0,05 & 2,5 & 1,25 & 1,25 & $59.219,8$ & 90 & $44.799,0$ & $47.763,3$ & 6,6 \\
7 & 0,05 & 5 & 2,5 & 2,5 & $59.219,8$ & 90 & $37.825,0$ & $39.755,1$ & 5,1 \\
8 & 0,05 & 10 & 5 & 5 & $59.219,8$ & 90 & $29.432,6$ & $34.083,2$ & 15,8 \\
Rata-rata & MAPE & & & & & & & & 10,8 \\
\hline
\end{tabular}

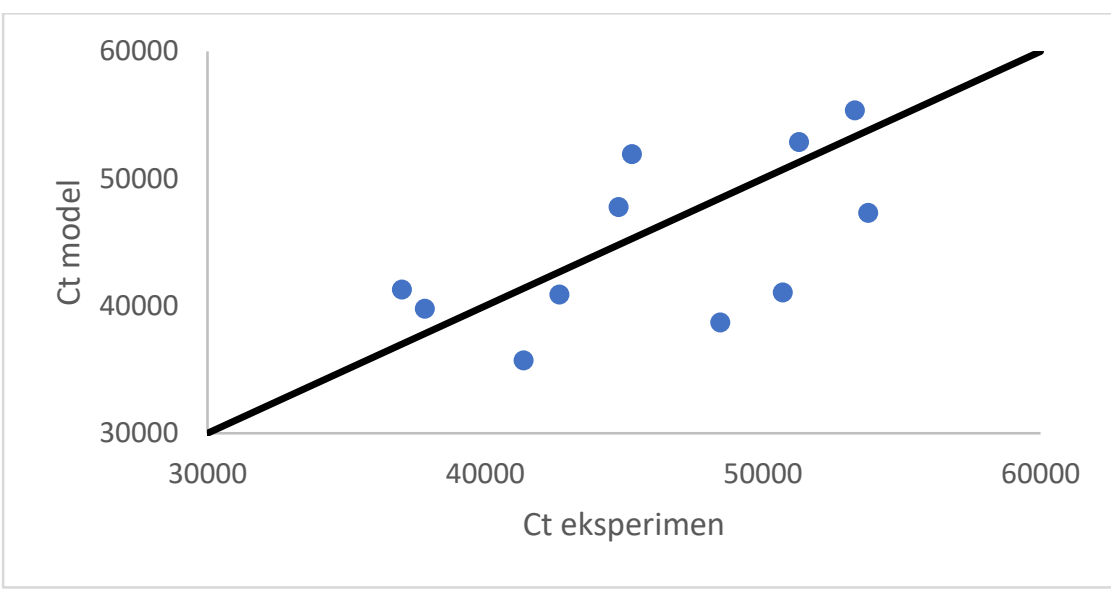

Gambar 2. Plotting antara data eksperimen dengan data terukur

Berdasarkan Tabel 8, model kinetik baru dapat memprediksi unjuk kerja proses koagulasi dengan rata-rata MAPE sebesar $10,8 \%$. Nilai ini berada pada rentang $10-20 \%$ dengan interpretasi good forecasting sehingga model ini (persamaan (17)) dapat dipertimbangkan sebagai tool untuk memprediksi unjuk kerja proses koagulasi dalam mengolah limbah cair industri tempe dengan jenis koagulan PAC dan tawas.

\subsection{Pertimbangan scale up}

Pada penelitian Hidayah (2018), proses koagulasi dioperasikan untuk mengolah 0,05 L limbah. Proses koagulasi dapat di scale up dengan volume limbah yang lebih besar dengan memperhatikan besaran intensif sebagai berikut:

Rasio volume limbah/massa koagulan $=0,005-0,02 \mathrm{~L} / \mathrm{g}$ 
Rasio COD limbah/massa koagulan $=5.141,84-23.687,92$ $\mathrm{mg} / \mathrm{g}$

Persentase PAC:tawas dalam massa koagulan $=100: 0-$ 50:50

Waktu proses $=0-90$ menit

Dengan memperhatikan besaran intensif tersebut, model kinetik yang diusulkan (persamaan (17)) dapat digunakan untuk memprediksi unjuk kerja proses koagulasi.

\section{Kesimpulan}

Kesimpulan yang dapat diambil dari studi ini adalah sebagai berikut:

a) Efisiensi pengurangan COD dipengaruhi oleh waktu proses, dosis koagulan dan jenis koagulan.

b) Model kinetik pseudo first order dan pseudo second order memberikan hasil prediksi yang bagus.

c) Model kinetik pseudo first order lebih dipilih dibandingkan pseudo second order karena alasan pseudo first order lebih sederhana.

d) Model kinetik baru berhasil disusun dan divalidasi dengan nilai MAPE rata-rata $10,8 \%$.

e) Model kinetik baru dapat dipertimbangkan untuk digunakan dalam memprediksi unjuk kerja proses koagulasi pada pengolahan limbah cair industri tempe dengan koagulan PAC dan tawas karena nilai MAPE nya di bawah $20 \%$.

f) Penyempurnaan model perlu dilakukan agar menghasilkan akurasi yang lebih baik.

\section{Ucapan Terimakasih}

Penulis mengucapkan terimakasih kepada Jurusan Teknik Kimia, Fakultas Teknik, Universitas Sultan Ageng Tirtayasa atas dukungan dalam penyelesaian studi ini.

\section{Daftar Pustaka}

Adeogun, A.I. \& Balakrishnan, R.B., 2017, Kinetics, isothermal and thermodynamics studies of electrocoagulation removal of basic dye rhodamine B from aqueous solution using steel electrodes, Appl Water Sci, Vol.7, 1711-1723.

Ayni, L.N. \& Ningsih, E., 2021, Pengolahan Limbah Cair Tekstil dengan Menggunakan Koagulan $\mathrm{FeCl}_{3}$, Seminar Nasional Teknologi Industri Berkelanjutan I (SENASTITAN I) ISSN: 2775-5630. Surabaya, 6 Maret 2021, Fakultas Teknologi Industri, Institut Teknologi Adhi Tama Surabaya.

Hidayah, H.N.A., 2018, Pengolahan Limbah Cair Industri Tempe untuk Menurunkan Kadar Chemical Oxygen Demand (COD) dengan Metode Koagulasi Menggunakan Koagulan Poly Aluminium Chloride (PAC) dan Aluminium Sulfat. Skripsi. Yogyakarta: Universitas Islam Indonesia.

Khair, U., Fahmi, H., Hakim, S.A., Rahim, R., 2017, Forecasting Error Calculation with Mean Absolute Deviation and Mean Absolute Percentage Error. IOP Conf. Series: Journal of Physics: Conf. Series Vol. 930, 012002.

Lewis, C.D., 1982, Industrial and business forecasting methods. London: Butterworths.
Moelyo, M., 2012, Pengkajian Evektifitas Proses Koagulasi dalam Memperbaiki Kualitas Limbah Industri Penyamakan Kulit - Sukaregang, Garut, Jurnal Teknik Hidraulik, Vol. 3, No. 2, 169-182.

Ngteni R., Hossain, Md.S., Kadir M.O.A., Asis A.J. \& Tajudin Z., 2020, Kinetics and Isotherm Modeling for the Treatment of Rubber Processing Effluent Using Iron (II) Sulphate Waste as a Coagulant, Water, Vol. 12, 1747.

Ohale, P.E., Onu, C.E., Ohale, N.J. \& Oba, S.N., 2020, Adsorptive kinetics, isotherm and thermodynamic analysis of fishpond effluent coagulation using chitin derived coagulant from waste Brachyura shell, Chemical Engineering Journal Advances, Vol. 4, 100036.

Quirk, T.J., 2020. Excel 2019 for Engineering Statistics: A Guide to Solving Practical Problems, Second Edition. Springer.

Sutiyono, 2006, Pemanfaatan Bittern sebagai koagulan pada limbah Cair Industri Kertas. Jurnal Teknik Kimia Vol. 1, No. 1 .

Xiao, Y., Azaiez, J. \& Hill, J.M., 2018. Erroneous Application of Pseudo-Second-Order Adsorption Kinetics Model: Ignored Assumptions and Spurious Correlations, Ind. Eng. Chem. Res., Vol. 57, No. 7, 2705-2709. 